EVALUATION

AEC-- 95

\title{
GAS COOLED FAST REACTOR
}

ZFCFIVED

JUL 051995

OSTI

JUNE 1972

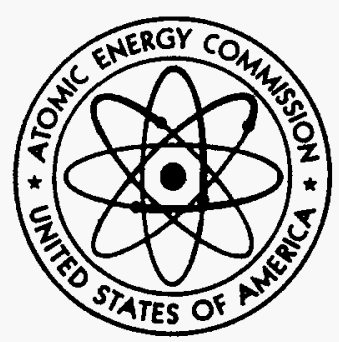

DIVISION OF REACTOR DEVELOPMENT AND TECHNOLOGY

U.S. ATOMIC ENERGY COMMISSION 


\title{
AN EVALUATION
}

OF

\section{I'HE GAS COOLED FAST REACTOR}

JUNE 1972

\section{DISCLAIMER}

This report was prepared as an account of work sponsored by an agency of the United States Government. Neither the United States Government nor any agency thereof, nor any of their employees, makes any warranty, express or implied, or assumes any legal liability or responsibility for the accuracy, completeness, or usefulness of any information, apparatus, product, or process disclosed, or represents that its use would not infringe privately owned rights. Reference herein to any specific commercial product, process, or service by trade name, trademark, manufacturer, or otherwise does not necessarily constitute or imply its endorsement, recommendation, or favoring by the United States Government or any agency thereof. The views and opinions of authors expressed herein do not necessarily state or reflect those of the United States Government or any agency thereof.

\author{
DIVISION OF REACTOR DEVELOPMENT AND TECHNOLOGY
}

\author{
U.S. ATONIC ENERGY COMMISSION
}

DISTRIBUTION OF THES DOCUMENT IS UNLIMTED 


\section{DISCLAIMER}

Portions of this document may be illegible electronic image products. Images are produced from the best available original document. 
Page

I. INTRODUCTION $\ldots \ldots \ldots \ldots \ldots \ldots \ldots \ldots \ldots \ldots \ldots \ldots \ldots \ldots \ldots \ldots \ldots \ldots$

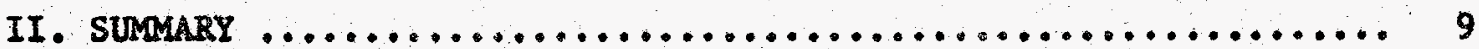

III. BASIS FOR WASH-1089 AND ASSOCIATED EVALUATIONS $\ldots \ldots \ldots \ldots \ldots \ldots 13$

Background $\ldots \ldots \ldots \ldots \ldots \ldots \ldots \ldots \ldots \ldots \ldots \ldots \ldots \ldots \ldots \ldots \ldots \ldots \ldots \ldots \ldots$

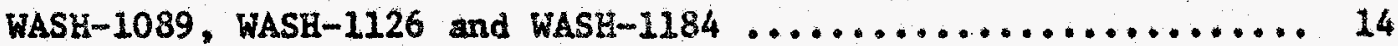

IV. GCER DESIGNS PRESENTED IN WASH-1089 $\ldots \ldots \ldots \ldots \ldots \ldots \ldots \ldots \ldots \ldots \ldots 17$

ORNL Working Group ............................ 17

Oxide Fueled GCFR Degigns ....................... 17

Carbide Fueled GCFR Design ........................ 19

v. CHANGES SUBSEQUENT TO EARLIER EVALUATION $\ldots \ldots \ldots \ldots \ldots \ldots \ldots \ldots .22$

Fuel Element Degign Changes $\ldots \ldots \ldots \ldots \ldots \ldots \ldots \ldots \ldots \ldots \ldots \ldots \ldots . \ldots 22$

Possible Altemate Development Approach $\ldots \ldots \ldots \ldots \ldots \ldots \ldots \ldots \ldots$

Further Plant Design Modification .................... 24

vI. DESCRIPTION OF DEMONSTRATION PLANT CONCEPTUAL DESIGN $\ldots \ldots \ldots \ldots 25$

Plant Configuration ............................. 25

Secondary Containment ........................... 27

Primary syetem ............................... 27

Reactor Core $\ldots \ldots \ldots \ldots \ldots \ldots \ldots \ldots \ldots \ldots \ldots \ldots \ldots \ldots \ldots \ldots \ldots \ldots \ldots \ldots . \ldots \ldots$

VII. IMPACT OF MORE RECENT GCFR DEVELOPMENT ON WASE-1089

EVALUATTON ................................ 32

Major Technical Changes Subsequent to WASH-1089 .......... 32

Component Development Needs ....................... 32

Fuel and Core Development Needs $\ldots \ldots \ldots \ldots \ldots \ldots \ldots \ldots \ldots \ldots \ldots$

Safety Needs .................................. 38

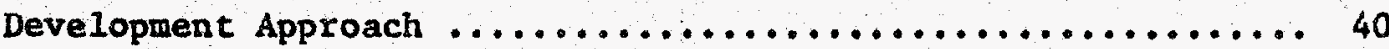

vIII. concLUSIONS $\ldots \ldots \ldots \ldots \ldots \ldots \ldots \ldots \ldots \ldots \ldots \ldots \ldots \ldots \ldots \ldots \ldots \ldots \ldots, 43$

IX. REFERENCES $\ldots \ldots \ldots \ldots \ldots \ldots \ldots \ldots \ldots \ldots \ldots \ldots \ldots \ldots \ldots \ldots \ldots \ldots \ldots \ldots \ldots$ 
Table

1. Sumary of Oxide-Fueled GCFR Design Characteristics ......... 18

2. Comparison of Oxide and Carbide Fueled GCFR Designs ........... 20

\section{F1gure}

1. Development Time Scales .......................... 11

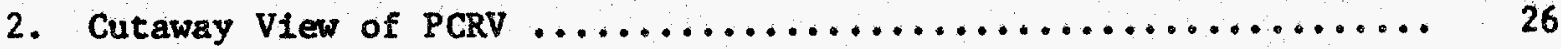

3. Schematic of Fuel Element Pressure Equalization System ....... 31

4. Phases in Achleving IMFBR Program objectives ............. 41

5. Utility Acceptance Requirements for LMFBR Plants ........... 42 
AN EVALUATION OF THE GAS COOLED FAST REACTOR

I

\section{INTRODUCTION}

Although most of the development work on fast breeder reactors has been devoted to the use of liquid metal cooling, Interest has been expressed for a number of years in alternative breeder concepts using other coolants. One of a number of concepts in which interest has been retalned is the Gas-Cooled Fast Reactor (GCFR). As present1y envisioned, 1t would operate on the uranium-plutonium mixed oxide fuel cycle, similar to that used in the IIquld Metal Fast Breeder Reactor (LMFBR), and would use hellu gas as the coolant.

The long-term objective of any new reactor concept and the incentive for the government to support its development is to help provide a selfoustainlng, competitive industrial capability for producing economical power in rellable and safe manner. Successful achievement of this objective is requaxed to perwlt the utilities, and others, to consider the concept wable option to exiating power production systems and to gain public acceptance of new form of power production. It is only after this is achieved that the utilities and industry could make the heavy, long-terw cowitments of resources in funds, faclilties and personnel to provide the traasition from the early experimental factlities and demonstration plants to full scale comercial reactor power plant systems. Consistent with the policy egtablished for all power reactor 
developwent programs, the GCFR would require the successful accomplishment of three baste phases:

- An Initlal research and development phase in which the basic technical aspects of the GCFR concept are confimed, involving exploratory development, laboratory experiment, and conceptual engineering.

- A second phase In which the engineering and manufacturing capabilities are developed. This includes the conduct of indepth engineering and proof testing of first-of-a-kind components, equipment and systems. These would then be Incorporated into experimental installations and supporting test facilities to assure adequate understanding of design and performance characteristics, as well as to gain overall experience associaced with major operational, economic and environdental parameters. As these research and developanent efforts progress, the technological uncertainties would need to be resolved and decision points reached that would permit developwent to proceed with necessary confidence. When the technology is sufficiently developed and confidence in the gystem is attained, the next stage would be the construction of large demonstration plants. 
A third phase in which the utilities make large scale comaltwents to electric generating plants by developing the capability to manage the design, construction, test and operation of these power plants in a safe, reliable, economic, and environmentally acceptable manner.

Significant experience with the Light Water Reactor (LWR), the High Temperature Gas-Cooled Reactor (HTGR) and the Liquid Metal Fast Breeder Reactor (LMFBR) has been galned over the past two decades pertaining to the efforts that are required to develop and advance nuclear reactors to the point of public and commercial acceptance. This expertence has clearly demonstrated that a logical progression through each of the three phases is an extremely difficult, time consuning and costly undertaking, requiring the highest level of technical management, professional competence and organization ski11s. This has again been demonstrated by the recent experience in the expanding LWR design, construction and licensing activities wich emphasizes clearly the need for even stronger base technology and englneering efforts than were Inftially provided, although these were satisfactory in many cases for the first experiments and demonstration plants. The LMFBR program, which is relatively well advanced In its development, tracks closely this LWR experience and has further reinforced thls need as Its applies to the technology, development and engineering application areas. 
It should also be kept in mind that the large backlog of commitments and the shortage of qualified engineering and technical management personnel and prooftest facilities in the government, in industry and in the utilities makes it even more necessary that all the reactor systems be thoroughly designed and tested before additional significant comitment to, and construction of, commercial power plants is initiated.

The large scale commitments to the uranium-plutonfum fuel cycle through purchases of the LWRs and the substantial investment of the Nation's resources engendered by these commitments led the U. S. Atomic Energy Commission (AEC), Division of Reactor Development and Technology to Initiate reviews in 1966 of the technical status and the possible benefits implicit in the development of the various reactor concepts belng considered in the civilian nuclear power program for meeting future power needs. These reviews were needed to help provide guidance on making effective use of our national resources and help determine the requirements for, and allocations of, these resources. With regard to the GCFR, the AEC evaluated this concept in 1969 and 1ssued "An Evaluation of Gas-Cooled Fast Reactors," WASH-1089, Apri1 1969, along wth a companion report "An Evaluation of Alternate Coolant Fast Breeder Reactors," WASH-1090, Apr11 1969.

The GCFR designs evaluated in WASH-1089 were based, in large measure, on information provided by the single industrial developer of the GCFR, and 
therefore, the report generally reflected this viewpoint and enthusiasm. The information in WASH-1089 was used as input to the subsequent systems analysis (WASH-1098) and cost-benefit studies (WASH-1126, USAEC, "Cost-Benefit Analysis of the U.S. Breeder Reactor Program," 1969 and WASH-1184, USAEC, "Updated (1970) Cost-BenefIt Analysis of the U.S. Breeder Reactor Program," January 1972).

WASH-1098, "Potential Nuclear Growth Patterns," December 1970, was prepared by the Systems Analysis Task Force (SATP) which was concerned with the development and application of a model of the v.S. electrical power economy. The model input data was provided by the individual task forces charged with the evaluation of the reactor concepts under congideration, including GCFR. The results of this evaluation, as it applied to GCFR, Indicated that largely because of the uncertainties in the cost estimates for both the LMFBR and the GCFR, it was not possible to draw a definitive conclusion concerning the soundness and desirability of conducting a parallel breeder program on the GCFR in addition to the LMFBR. Accordingly, WASH-1098 concluded that "the current state of knowledge is not sufficient to support a definitive evaluation of the potential of the GCFR against that of the LAFBR."

The consistent conclusion reached in the cost-benefit studies (WASH-1126 and -1184), viz., sufficient information is avallable to Indicate that 
the projected benefits from the LMFBR program can support a paralle1 breeder program, is highly sensitive to the assumptions on plant capital costs. With the recognition that even for ongoing concepts on which ample experience exists, capital costs and especially small estimated differences in costs are highly speculative for plants to be built 15 or 20 years from now, it is questionable whether analyses based upon such costa should constitute a major basis for decision making relative to the desirability of a parallel breeder effort.

In compliance with a request from the office of Science and Technology for further review of the GCFR at this time, the AEC has undertaken this internal assessment which examines the technical developments that have taken place in the continuing research and development and destgn efforts on the GCFR system. This request recognized that the GCFR has been In the Inttial research and development phase with emphasis on the developwent of basic GCFR technology. The progran has been carried out primarily at Gulf General Atomlc (GGA) and has been supported by governmentsponsored research at a level of about $\$ 1$ million per year over the past several years. The utility industry is supporting research and development on this concept at a level of about $\$ 1.4$ million per year. Total expenditures from 1963 to date on GCFR technology have amounted to approximately $\$ 17$ m1111on. 
The GCFR is still in the early phases of an overall R\&D effort notwithstanding the benefits expected to accrue to it from the HTCR and IMPBR programs. An adequate investigation of the problens associated with the GCFR concept to move forward toward their satisfactory resolution would require a substantial research and development program along the lines outlined herein with sufficient proof-testing of mafor components and systems to provide assurances comensurate with the large commitment and investment in such plants for large-scale power generation. Some prerequilites for such a program are provided by portions of mafor ongoing programs, e.g., some of the fuel development, physics and safety work in the LIquid Metal Fast Breeder Reactor (LMBR) progran and component development in the High Temperature Gas Reactor (HTGR) program. Also, component and plant operating and maintenance experience at the 330 WWe Fort St. Vrain reactor w111 provide important basic information. However, most of the critical and unique characteristics of the GCFR are not adequately represented in research and development programs on other concepts. In addition, the flexibility for resolution of such development and englneering problems normally required by the designers, constructors, and operators of even the more proven concepts is restricted due to the compact arrangement proposed for the GCFR. Consequently, if feastbility were to be confirmed through appropriate experimental reactor and other facility operation, the additional overall technical effort needed for such a full-scale program on the 
GCFR could be comparable in magnitude to the efforts on other major reactor development programs such as the LWR and IMTBR programs.

Experlence in reactor development programs in this country and abrosd has demonstrated that different organizations in evaluating the profected costs of introducing a reactor development program and carrying 1 to forward to the point of large-scale comercial utilization, would arrive at different estimates of the methods, scope of development and engineering efforts, and the costs and time required to bring that program to a stage of successful large scale application and public acceptance.

Based upon the extensive program required to bring a new concept to commercial utilization, and taking into account the benefits expected to accrue from progress in the LMFBR and HTGR programs over the next 5 years, the incremental cost to the government of a parallel breeder program of this type has been estimeted by the AEC to range up to about $\$ 2$ billion In undiscounted direct costs, (WASH-1184). The GCFR would require magnitude of funding up to this level in order to establish the necessary technology and engineerlng bases; obtain the required industrial capability; and advance through a series of test facilities, reactor experiments, and demonstration plants to a comercial GCFR, safe and suitable to serve as a major energy option for central station power generation in the utility environment. 


\section{SUMMARY}

The GCFR concept uses helium as the coolant gas, which leads to several potentially favorable attributes of the GCFR. Helium is both optically and neutronically transparent and does not become radioactive. The GCFR has a potentially high breeding ratio resulting largely from the coolant properties. Since the use of gas cooling requires a high coolant pressure to secure adequate heat transfer, the GCFR is subject to the possibility of depressurization accidents as well as loss-of-flow accidents. The potential for occurrence of these types of accidents requires resolution of significant reactor damage and safety questions which are unique to the GCFR concept. In addition, there are other outstanding engineering problems associated with safety, rellability and maintainability which differ significantly frow similar considerations for the HTGR and LMFBR.

The additional technical work done since the publication of WASH-1089 and WASH-1098, both by the AEC and private industry, and further definition of problem areas aided by discussions with the Regulatory staff and the Advisory Committee on Reactor Safeguards (ACRS) have served to reinforce the earlier conclusion of WASH-1089 that a substantial program would be needed to support the comercial introduction of the GCFR. This is particularly so since only limited effort on the GCFR is underway outside 
the United states and fenefits can accrue from signiflcant parallel development work and related large scale cowntwents in other countries such as is the case for the IMPBR concept. Beaed upon the Information currently avaliable, as discussed in this report, there have been no ignificant changes in the GCPR development status, relative to the total effort regulred for ita comerclal application, that would appreciably alter the general conclugions of WASH-1089.

Although the proponents of the GCPR concept would Intend to depend heav1ly upon the technology developed in the HIgh Temperature Gas Reactor (UTGR) program and, to the extent poss1ble, the technology of the IATBR program, the GCFR can be characterlzed as being in only the early stages of an overall development program. This should not be aurprising, since the goverment and Industrial funds expended on this concept through PY 1972 total less than $\$ 20$ million. With a significantly increased combitment to an RED program along with personsel and other resources made avallable on a high priority basis, the developsent time scale which could optlulstically be expected for development of the GCrR would have to be in the context of the approach and experience with the LWR, HTGR and LMFBR programs, FIg. 1. With the size of the major government and industrial Investment, recent experience with LWR's on problems arising in multiple comattments to full size power plants provides ample evidence of the necessity to provide a broad Industrial base and to conduct extensive, In-depth development and testing efforts addressed to all critical componeats 
Figure 1

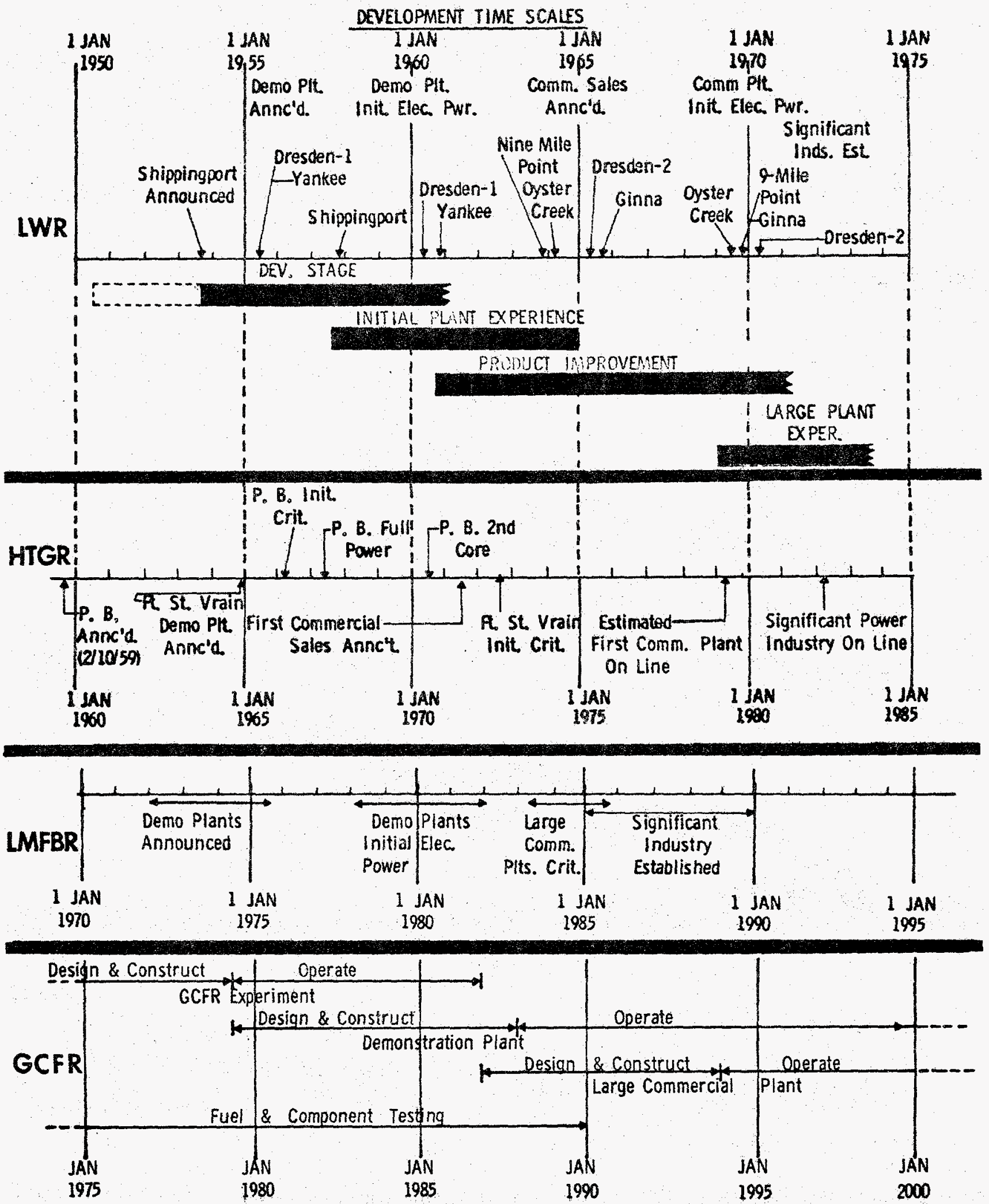


and systems throughout all profect phases. An overall full-scale program on the GCFR would be expected to cover those phases that are currentiy under consideration for the LMFBR Program. (See Figure 1 and Figure 4, p. 41). Such a program would Involve costs comparable to other reactor development programs (in the range of two billion dollars from the Government) In addition to large outlays and commitments by industry and the ut1lities. Such a GCFR program would have to take into account any overlappling or concurrent commitments and avallability of resources with the HTGR commercialization efforts. This, of course, is a problem faced. by other reactor programs as well. 


\section{BASIS FOR WASH-1089 AND ASSOCLATED EVALUATIONS}

\section{Background}

GCFR development was inftlated in November 1963 by the AEC under a contract with Gulf General Atomic (GGA)* to investigate the concept which had evolved fros earlier privately supported GCFR studies. The AEC-sponsored work outlined a development program that started with the objective of a gas-cooled fast reactor experiment of 50 MWt which was to lead to a demonstration power plant as a step towards a full-scale plant. An outcome of the next year of AEC sponsored R\&D (1964) was a conceptual design for a reactor experiment which would serve as a test bed for fuel development, and would provide experience in designing and constructing a special prestressed concrete reactor vessel (PCRV).

In the period 1965-68, the AEC and GGA continued studies of the GCFR. A conceptual design for a 1000 Me GCFR power plant was evolved which featured a horizoncal PCRV instead of the orlginal vertical arrangement and also differed in other Important respects from the orlginal concept. This effort incorporated 1deas of the utility companies, particularly as to the layout and design of the nuclear steam supply components from the viewpoint of operation, maintenance and safety. Also, a new design for a reactor experiment was developed to reflect engineering aspects of the new large plant design.

*Gulf General Atomic formerly was the General Atomic Division of General Dynamics. 
The 1000 MW GCFR reference conceptual des1gn prepared by GGA for study by the AEC Fast Breeder Reactor Alternate Coolant Task Force $2,3,4$ was an extension of the above conceptual design. The task force analyses were reported In WASH-1089 dated Apri1 1969. A brief description of the GCFR plant designs considered in this study is included in the next section. A more detailed description may be found in WASH-1089. During 1967, to satisfy the needs of the Alternate Coolant rask Force as well as to meet AEC contractual requirements, a Preliminary Development Plan for the GCFR was also prepared. 5

\section{WASH -1089 , WASH-1126, and WASH-1184}

The conclusfons of WASH-1089 were based upon the 1000 Me plant conceptual design provided to the Alternate Coolant Task Force. The development plan and costs projected in WASH-1089 were associated with bringing the concept to the stage of commercial introduction including construction and operation of a reactor experiment to help demonstrate the adequacy of the fuel performance.

As noted at the time WASH-1089 was published, the designs evaluated were based on information provided by developers of GCFR and generally reflected their viewpoints and opintons on achievable technology.

Based upon the Information in WASH-1089, the cost of development of a parallel breeder was estimated and examined in the context of the overall LMFBR development program. As noted in WASH-1126, "Cost-Benefit Analysis 
of the U.S. Breeder Reactor Program,"Apr11 1969, if the LMFBR were to be introduced in 1984 or earlier, it was concluded that sufficient benefits would be generated to support the cost of a parallel breeder program and still maintain a benefit-cost ratio in excess of one.

Although the LMFBR Introduction date was deferred to 1986 in WASH-1184, "Updated (1970) Cost-Benefit Analysis of the U.S. Breeder Reactor Program," January 1972, the conclusions remain essentialiy unchanged, viz.. a tentative case can be made to expand the industrial breeder base by establishing a parallel breeder program.

It should be stressed that the cost-benefit ratios derived in both WASH-1126 and WASH-1184 depend heav11y upon the assumed capital costs for the various power plants, eapecially the breeders. The sensitivity of the results to a slight increase in the capital cost of the GCFR was illustrated in WASH-1098 (page 6-50), where an increase of $7.7 \%$ in the assumed cost of a GCFR from 130 to 140 \$/KWe permitted the LMFBR to compete at an assumed cost of $150 \$ /$ KWe. The capttal cost studies performed over the past two years have confirmed the cenuousness of ut $111 z$ ing assumed smal1 capital cost differences such as these. Variations in design, plant location, labor productivity and cost, escalation, interest rates and periods of construction can readily produce capital cost differences of 10 to $15 \%$. Capital costs for all of the breeder designs considered in past studies were only best estimates at the time, normalized to some extent for unit costs. At present, while a reasonable capability to predict costs of 
LWR designs has been developed over the past few years, the calculated capital costs for plants In various locatlons in the U.S. based on relatively well established LWR cechnology, will vary $15 \%$ or more. other factors such as safety, seismologlcal, and environmental features can materially Increase estimated costs. On this basis, the use of capital cost comparisons between concepts yet to be developed and then to be built 15 or 20 years from now as a major basis for programatic dectsions and cholces is highly questionable. 


\section{GCPR DESIGNS PRESENTED IN WASH-1089}

\section{ORNL Working Group}

The gas-cooled fast reactor designs reviewed in WASH-1089 were developed by $\mathrm{GGA}^{2,3,4}$ Two oxlde fueled designs were submitted to the oak Ridge National Laboratory (ORNL) working group for evaluation. A carbide fueled design was also prepared by GGA, but it was submitted too late in the study to allow evaluation.

\section{Oxide Fueled GCFR Designs}

The two oxide fueled designs were designated "reference" and "derated" designs. Some principal characteristics of the two oxide fueled designs are given in Table 1 which has been modified from Table 2.1 of WASH-1089 to show the parameters for the latest avaflable 1000 MWe GCPR plant design. Design parameters are also shown for a 300 we demonstration plant.

The entire primary cooling system for the oxide designs was housed within a horizontal PCRV which contained the centrally located vertical reactor core, four steam generators and their associated circulators located in Internally isolated compartments at the ends of the vessel. The PCRV had double containment of all penetrations, individual standpipes above each core and blanket element, and a watercooled, but uninsulated, steel liner. The whole primary clrcuit flow path was confined within insulated ducting and shells surrounding the reactor and the stean generators; thus the main internal compartments were at substantially room temperature. These compartments were continuously purged with clean hellum. 
Table 1 Surarary of Oxide-Fueled GCFR Design Characteristics $\mathrm{s}^{\mathrm{a}}$

Viollatid tifn fib 1972 WA:li - lo 09

\begin{tabular}{|c|c|c|c|c|}
\hline & CCFR-4 Reference DeGIgn & GCFR-4D Derated Design & 300 wa thero Mante & $1000 \mathrm{MmPlant}$ \\
\hline \multicolumn{3}{|l|}{ Power } & 826 & $\cdots$ \\
\hline 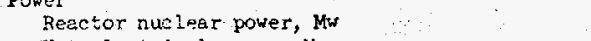 & 2530 & 2681 & 318 & 1000 \\
\hline $\begin{array}{l}\text { Wet eleatrical power, } \\
\text { Net themodynamic efficiency, } 6\end{array}$ & 1000 & 1000 & 37.6 & JA. 0 \\
\hline \multirow{2}{*}{\multicolumn{2}{|c|}{$\begin{array}{l}\text { ilet therrodynamic efficiency, } \\
\text { colant }\end{array}$}} & & Hollum & Hellua \\
\hline Compostion & & Felium & 1250 & 1250 \\
\hline $\begin{array}{l}\text { Core iniet pressure, psia } \\
\text { Rezctor pressure arop psi }\end{array}$ & $\frac{1250}{42.6}$ & $\begin{array}{l}1250 \\
42.6\end{array}$ & 40 & $60(4,8 \%)$ \\
\hline $\begin{array}{l}\text { Reactor pressure arop, psi } \\
\text { Flow rate, } 1 \mathrm{~b} / \mathrm{hr}\end{array}$ & $12.53 \times 10^{6}$ & $14.44 \times 10^{6}$ & $5.47 \times 10^{6}$ & B.A. \\
\hline \multicolumn{2}{|l|}{$\begin{array}{l}\text { Flow rate, } 1 \mathrm{~b} / \mathrm{hr} \\
\text { Temperatures, }{ }^{\circ} \mathrm{F}\left({ }^{\circ} \mathrm{C}\right)\end{array}$} & $589(308)$ & 593 & $662(317)$ \\
\hline $\begin{array}{l}\text { Keactoriniet } \\
\text { Core iniet }\end{array}$ & $635(334)$ & $595(323)$ & $\because$ & $\because$ \\
\hline $\begin{array}{l}\text { Core cor let } \\
\text { Reactor outlet }\end{array}$ & $\begin{array}{l}1183(639) \\
1190(643)\end{array}$ & $\begin{array}{l}1088(587) \\
1094(590)\end{array}$ & 2007 & $1130(594)$ \\
\hline \multirow{2}{*}{\multicolumn{5}{|c|}{$\begin{array}{l}\text { Steam plant cenditions } \\
\text { Ieaving Superhoster }\end{array}$}} \\
\hline & & & & \\
\hline $\begin{array}{l}\text { Fressure, psia } \\
\text { Temperzture, op }\end{array}$ & $\begin{array}{l}2515 \\
1000\end{array}$ & 900 & $\begin{aligned} 2900 \\
875\end{aligned}$ & $\begin{aligned} 2300 \\
925\end{aligned}$ \\
\hline \multirow{2}{*}{\multicolumn{5}{|c|}{ core therasi periormance (st 100 s power) }} \\
\hline & & & & \\
\hline \multicolumn{5}{|l|}{ 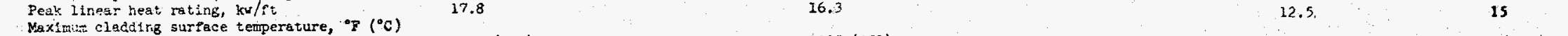 } \\
\hline $\begin{array}{l}\text { Norinal } \\
\text { not }\end{array}$ & $1315(713)$ & $1205(652)$ & $\therefore$ & $\therefore$ \\
\hline \multirow{2}{*}{\multicolumn{5}{|c|}{$\begin{array}{l}\text { Local hot spot } \\
\text { Maxtmus lntertor fuel texperature, } \theta \cdot \gamma(\cdot c)\end{array}$}} \\
\hline & $4935(2724)$ & $4765(2629)$ & $-\alpha$ & $\therefore$ \\
\hline Loce. no: spot & $5205(2824)$ & $5039(2787)$ & $\because$ & $\ddot{\cdots}$ \\
\hline Peak-to-Everage core power ratio &. .47 & 1.47 & $\because$ & $\because$ \\
\hline Yeen core powez dersity, kw(ti) /11ter & 230 & 260 & $\ddot{m}$ & $\because$ \\
\hline \multicolumn{5}{|l|}{$\begin{array}{l}\text { Nean plesile quei reting, ww/th)/kg } \\
\text { core and blarixet deacription }\end{array}$} \\
\hline $\begin{array}{l}\text { Active core voiume, ilters } \\
\text { Ales }\end{array}$ & 8510 & 9712 & & \\
\hline Act tue care length, cin (In.) & $148.2(58.4)$ & $154.8(60.9)$ & $\ldots$ & 7900 \\
\hline Active core diameter, cru (In.) & $269.5(106.0)$ & $281.5(120.8)$ & $101(40)$ & $136(54)$ \\
\hline Axlal oleniket thfeiness, of $(1 \mathrm{n})$. & $60(23.6)$ & $60(23,6)$ & $201(80)$ & $\cdots$ \\
\hline Reatel biancet thicknesa, ca (1n) & $51(20.1)$ & $51(20.1)$ & - & $\cdots$ \\
\hline Core Lergth-so-diazeter ratio & & & $\therefore$ & $\cdots$ \\
\hline $\begin{array}{l}\text { Fuel materisl (eare) } \\
\text { Fuel material (blenket) } \\
\text { Fuel tistrijution }\end{array}$ & 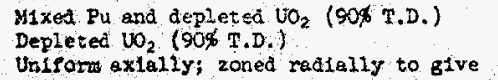 & 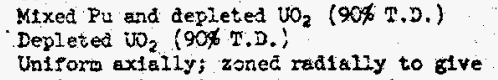 & $\begin{array}{l}\text { Wued Pu \& depieted von } \\
\text { Depleted } \mathrm{HO}_{2}\end{array}$ & - \\
\hline & 1.2 redial maximum-to-mean rstio & 1.2 radial maximu-to-mean sattlo & & \\
\hline \multicolumn{5}{|c|}{ a Tabulazed vaiues are resuits of ORRE revies. } \\
\hline \multicolumn{5}{|c|}{ 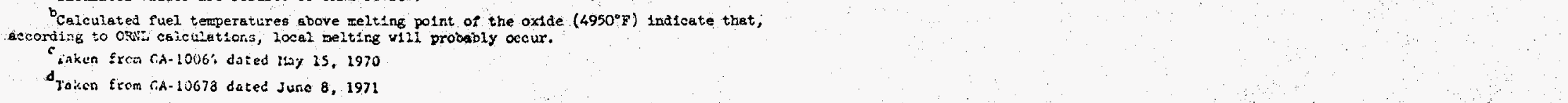 } \\
\hline
\end{tabular}


The reactor core was assembled inside a vertical cylindrical steel core barrel, which spanned the PCRV from top to bottom. The core barrel served the multiple purpose of supporting the core grid plate, containing and directing the flow of coolant, and acting as a thermal shield. The core consisted of bundles of small diameter fuel rods contained in thinwalled square metal boxes. These fuel boxes were cant1levered downard from the deep section upper grid plate.

Both of the oxide fueled designs had free standing stainless steel-clad pins about $0.3 \mathrm{in.}$ in diameter. The cladding surface was intentionally roughened over approximately 60 to $70 \%$ of the active core length to enhance the heat transfer coefficlent in the downstream portion of the core and thereby prevent excessive cladding surface temperatures.

The designs also inciuded an alternate fuel element design that had a pressure equalizing collection systen to vent the fission product gases to a receptacle that was isolated from the coolant system. The objective of this manffolding system was to elininate the large gas pressure differential across the cladding whlle preventing the fission product gases from escaping into the coolant.

\section{Carbide Fueled GCFR Design}

An advanced GCFR design to exploit the high density and excellent thermal conductivity of carbide fuel was also prepared by GGA. The carbide fuel design was submitted too late in the study period to be subjected to a technical evaluation. However, the design data were reviewed. (See Table 2). More details on this design are contained in WASH 1089 . 
Table 2 Comparison of Oxide and Carbide Fueled GCFR Designs*

\begin{tabular}{|c|c|c|}
\hline & $\begin{array}{l}\text { Reference } \\
\text { Oxfae Fueled } \\
\text { Reactor }\end{array}$ & $\begin{array}{l}\text { Advanced } \\
\text { Carblde Fueled } \\
\text { Reactor }\end{array}$ \\
\hline \multicolumn{3}{|l|}{ Common conditions } \\
\hline $\begin{array}{l}\text { Coolant } \\
\text { Total pumping power fraction, } \phi \text { of } \\
\text { thermal }\end{array}$ & $\begin{array}{l}\text { Hellum } \\
4\end{array}$ & Hellum \\
\hline $\begin{array}{l}\text { Deslgn maxlmum cladding temperature, }{ }^{\circ} \mathrm{C} \\
\text { Cladding (stainless steel) thickness-to- } \\
\text { diameter ratio }\end{array}$ & $\begin{array}{l}700 \\
0.04\end{array}$ & $\begin{array}{l}700 \\
0.04\end{array}$ \\
\hline Control-rod and structure blockage, $\varnothing$ & 10 & 10 \\
\hline Net electric output, Nw & $1, \infty 00$ & 1,000 \\
\hline $\begin{array}{l}\text { Average enrichment of fresh core fuel, } \\
{ }^{239} \mathrm{Pu}+34 \mathrm{I} \mathrm{Pu} / \mathrm{U}+\mathrm{Pu}\end{array}$ & 0.127 & 0.127 \\
\hline \multicolumn{3}{|l|}{ Appropriate core proportions } \\
\hline Core length-to-alameter rat1o & 0.55 & 0.40 \\
\hline Core volume, 11ters & 8,510 & 4,030 \\
\hline Active length, $\mathrm{cm}$ & 148 & 93 \\
\hline Active diameter, cm & 270 & 234 \\
\hline Fuel volume fraction & 0.29 & 0.30 \\
\hline Coolant volume fraction & 0.55 & 0.53 \\
\hline Rod dlameter, cm & 0.805 & 0.736 \\
\hline Number of rods & 40,000 & 37,000 \\
\hline \multicolumn{3}{|l|}{ operating conditions } \\
\hline $\begin{array}{l}\text { Core pressure, psi } \\
\text { Gas inlet temperature, }{ }^{\circ} F\end{array}$ & $\begin{array}{r}1,250 \\
644\end{array}$ & $\begin{array}{r}1,750 \\
567\end{array}$ \\
\hline $\begin{array}{l}\text { Gas outlet temperature, } \mathrm{F} \\
\text { Steam conditions }\end{array}$ & 1,175 & 1,057 \\
\hline Outlet temperature, ${ }^{\circ} \mathrm{F}$ & 1000 & 900 \\
\hline Reheat temperature, ${ }^{\circ} \mathrm{F}$ & 1000 & 900 \\
\hline Feed temperature, ${ }^{\circ} \mathrm{F}$ & 375 & 275 \\
\hline Pressure, pst & 2,400 & 1,800 \\
\hline Net plant efficiency & 0.395 & 0.373 \\
\hline \multicolumn{3}{|l|}{ Performance } \\
\hline $\begin{array}{l}\text { Maximum rod heat load, } \mathrm{kw} / \mathrm{ft} \\
\text { Speciflc power, total } \mathrm{Mw}(\mathrm{th}) / \mathrm{kg} \text { core } \\
\text { flssile at startup }\end{array}$ & $\begin{array}{l}18 \\
0.90\end{array}$ & $\begin{array}{l}30 \\
1.50\end{array}$ \\
\hline Power denslty, $\mathrm{kw} /$ liter & 277 & 615 \\
\hline Conversion ratio, average & 1.51 & 1.60 \\
\hline Assumed maximum burnup, Mwd/MT & $10^{5}$ & $1.4 \times 10^{5}$ \\
\hline Core life, years & 2.29 & 2.49 \\
\hline Out-of-plie time, years & 1.0 & 0.5 \\
\hline $\begin{array}{l}\text { Fractional increase in fissile plutonium } \\
\text { per cycle }\end{array}$ & 0.27 & 0.62 \\
\hline Geometric doubling time, years & 8.8 & 4.3 \\
\hline
\end{tabular}

*uneveluated characteristics presented by General Atomic. 
Because of the potential advantages of the carbides and nitrides as fuel for the LMFBK or the GCFR, research has continued. The current advanced fuel technology program at Los Alamos Sclentific Laboratory involves an effort of approximately $\$ 750,000$ per year and includes the irradiation of carbide and nitride fuel pins in the EBR-II reactor and transient tests in the TREAT facility. The current status of technology indicates that low density carbide fuels have promise for high burnup and high power densicy reactor applications. The major apparent problem involves swelling due to retention of fission gases. The retention of fission gas followed by a sudden release of this gas in the event of a temperature transient presents a potential safety problem that could result in clad distortion or failure.

The multi-cavity PCRV which was used in this design consisted of a vertical cylindrical block of prestressed and reinforced concrete contalning multiple cavities in which the reactor core and the steam generators were individually housed. The cavities were interconnected by passages in the concrete through which the helium coolant flowed. The helfum circulators, both main and auxiliary, were mounted in double containment penetrations in the vessel. The general arrangement of the components in the $\mathrm{PCRV}$ is shown in Fig. 2 of section VI. 


\section{CHANGES SUBSEQUENT TO EARLIER EVALUATION}

\section{Fuel Element Destgn Changes}

Subsequent to the issuance of WASH-1089, certain changes in the reference GCFR fuel element design evolved. One change was a modified design for fuel venting as a means for equalizing the gas pressure insicie and outside of the fuel cladding. GCFR fuel venting as first conceived ${ }^{2}$ used tight seals between the fuel elements and the grid plate and required the recovery and storage of the released fission-gas effluent in gas cylinders. Furcher design fteration led to a proposed system in which fission gases would be removed from the element by a small differential pressure and diluted by a small stream of reactor coolant helium at the element-togrid-plate connection. This approach would eliminate the requi rement for a gas-tight joint where the fuel element joins the grid plate. The mixture of fission gases and hellum diluent would be passed through a system of traps similar to those used in an HTGR helium purffication system. The residus purified helium would be returned to the suction of the main helium circulator. This change in the venting design led to the adoption of fuel venting as a reference conceptual GCFR design feature by GGA. It should be noted, however, that the use of vented fuel eliminates the noble gas fission product containment feature regarded as an important advantage of non-vented fuel, with its attendant implications on other plant characteristics such as maintenance and fuel handling. Another major change was a lowering of the cladding hot-spot temeratures 
by modified core coolant orfficing design and physics design fncluding partial reloading.

\section{Possible Alternate Development Approach}

With the decreased cladding temperature and the use of fuel venting in mind, an alternate development approach was chosen by the designer, namely, that the first GCFR facilfty could be a power-producing prototype plant based as closely as possible on IMFBR fuel and HTGR plant technologies rather than a reactor experiment. In the latter half of 1968 a conceptual design study of a 330 MWe GCFR Demonstration Plant was prepared. 6 This design was based on the proposed use of fuel venting and a cladding hot-spot temperature of $1382^{\circ} \mathrm{F}$, which was lower than for earlier designs. This revised new plant design also incorporated the use of a PCRV of the cylindrical vertical multi-cavity type being developed for large HTGR plants, which is quite different from the type used in the WASH-1089 reference and derated designs. The primary virtue of the multi-cavity PCRV is the easier accessibility of primary system components.

An associated draft development program plan was also prepared, based initially on this conceptual design. Much of the overall GCFR effort subsequent to WASH-1089 has been addressed to the demonstration plant design rather than to a 1000 Me plant design. 


\section{Further P1ant Design Modiflcation}

Additional design work has been performed which is addressed to a demonstration plant design. A reference demonstration plant design ${ }^{7}$ was adopted by GGA in March 1970 based on a further $90^{\circ} \mathrm{F}$ reduction in cladding hot-spot temperature $\left(1292^{\circ} \mathrm{F}\right)$ and improved predicted plant performance, resulting from more sophisticated reactor physics design and from resuperheating the steam after expansion through the circulator drive turbines. (See Table 1 of Section IV).

Subsequent to completion of the 300 WWe demonstration plant conceptual design, effort has been conducted on a more detailed safety analysis which was developed for this concept in collaboration with utility operating engineers and nuclear safety specialists representing the ut11ity sponsors. This work has resulted in a Preliminary Safety Information Document, which is now being reviewed by the AEC Regulatory Staff Including the Advisory Comittee for Reactor Safeguards (ACRS). A number of meetings on this document have been held and are continuing.

The latest GGA draft development program plan (Draft GA-A10788) is based on a systematic review of the 300 MWe GCFR demonstration plant conceptual design to define the problems that would require development work for a demonstration plant project. The scope of the plan is limited to the development needs of one GCFR demonstration plant by a single industrial participant, and thus encompasses a lesser program than the work described in WASH-1089 which was intended to cover an entire program with a competitive industrial capability through full comercial introduction of the GCFR. 


\section{VI}

\section{DESCRIPTION OF DEMONSTRATION PLANT CONCEPTUAL DESIGN}

The demonstration plant design is described because it is a more recent design than the latest available 1000 Mie GCFR plant design. The description emphasizes the nuclear steam supply system. The remainder of the plant is typical of modern high-temperature steam-turbine practice. The design 18 based on the utilization of LMPBR physics and fuel technology to the extent possible and on the continuing development of the component technology that forms the basis of the 40 MWe prototype HTGR at Peach Bottom, Pennsylvanla, and the 330 MWe Fort St. Vrain HTGR Generating Station in Colorado and follow-on commercial HTGR's. Table 1 of Section. IV gives the principal parameters.

\section{Plant Conflguration}

The plant is housed in reactor bullding, a fuel service bullding, and a turbine building. The reactor building contains the PCRV, which in turn contains the core, the helfum primary coolant system and the steam generators. In addition, the reactor building functions as a secondary contalnment structure and also includes the fuel handing area and some reactor plant process and service systems. The fuel storage pool is in a fuel service building adjacent to the reactor building.

The configuration of the reactor and 1ts associated primary circult components, all of which are housed within the PCRV, is shown in Fig. 2 of 


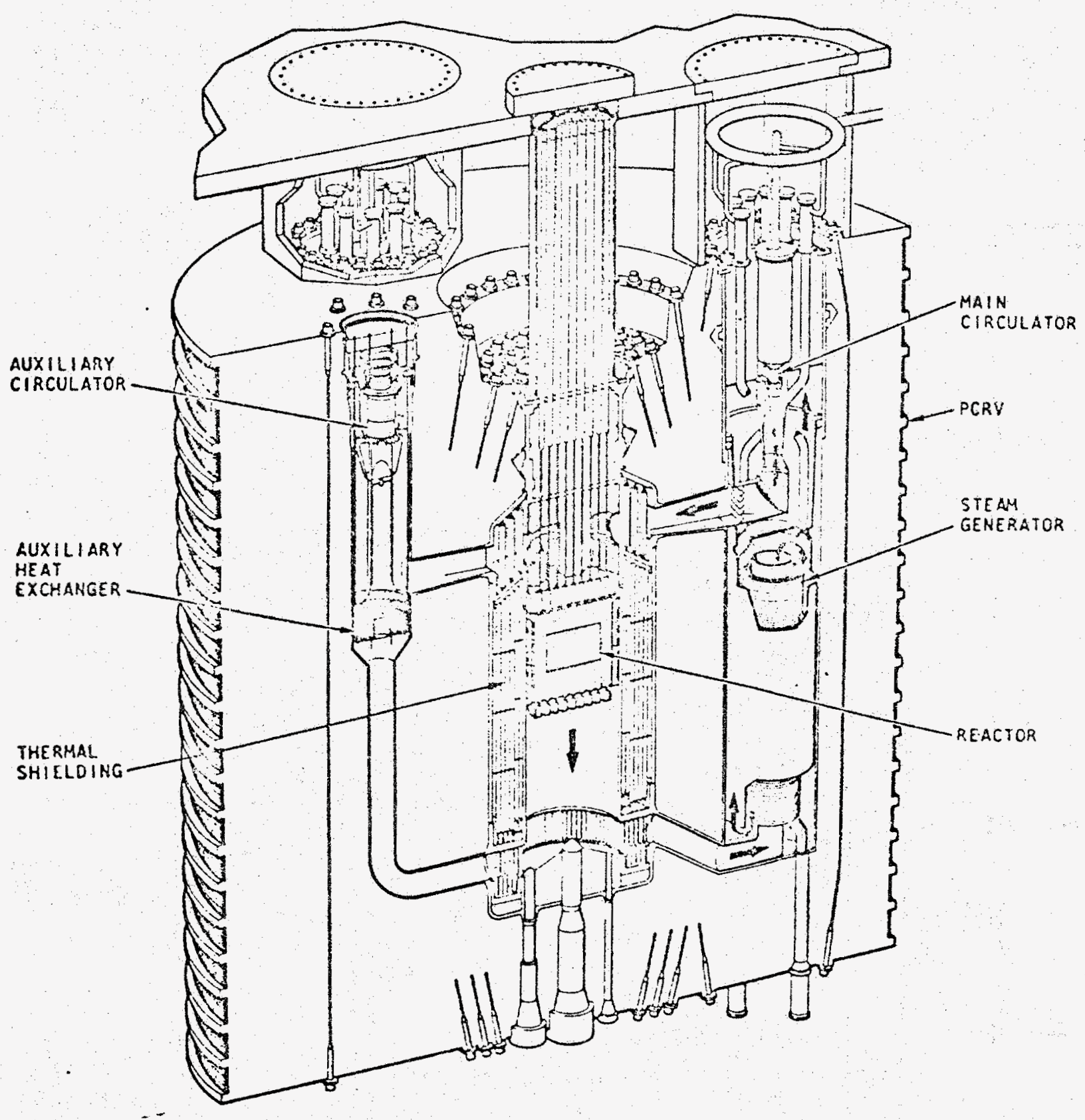

Figure 2 Cutaway view of PCRV showing the primcipal comporents of the nuclear steam supply sustem 
this section. The PCRV is similar in principle to the PCRV's that have already been bullt in Europe and Great Britain and is also similar to GGA's large commercial HTGR design. An Inner steel Iner makes the PCRV leaktight. The penetrations are provided with steel closures and structurally independent flow-1imiting features where necessary to 1imit the depressurization rate in the event of primary barrier fallure to a value that would not feopardize core cooling. The large penetrations are closed by concrete plugs designed so as to always be in compression and held in place by two structurally Independent and redundant means. These concrete plugs would not normally be removed and thus are folned to the vessel iner by seal welds. The liner is insulated by a thermal barxiex, and cooling of the liner and penetrations is provided by cooling tubes on the concrete stde of the steel 11ner. ThIs PCRV is designed with redundancy of tension members that are inspectable and replaceable to preclude a gross failure of the pressure vessel.

\section{Secondary Containment}

To limit the consequences of a possible penetration closure failure, separate secondary containment is provided, similar to that proposed for the large comercial HTGR's. It performs two functions: it ensures a minimua coolant pressure $(\sim 2 \mathrm{~atm})$ for core cooling following an accidental primary system depressurization and it confines fission products that potentially could be released from the fuel.

\section{$\frac{\text { Primary Reactor System }}{:}$}

The reactor coolant system contains three main 10ops, each with Independent steam generators and circulators, and three auxiliary loops, each 
with tts own circulator and heat-rewoval system which are used as backup for the main loops for shutdown cooling. The steam generators and their assoclated circulators are housed in vertical cavitles in the walls of the PCRV surrounding the reactor core. The helium coolant, at a pressure of about $1250 \mathrm{psia}$, flows downward through the core, where it is heated to a temperature of about $1010^{\circ} \mathrm{F}$ at rated capacity. The flow is also downward across the tube banks of the helically colled, once-through steam generators to accomodate the use of upflow bolling. This necessitates appropriate reverals in the gas flow path. These flow reversais are obtalned by directing the core exit gas up through a central hole In the boller and down through the tube bundles, up again around the boller shells and then to top-mounted circulators from which the gas is discharged to the reactor top plenum at a temperature of about $595^{\circ} \mathrm{F}$.

Main helium is circulated by three steam turbine-driven circulators of the type developed for the HTGR, wh1ch employs a single axial compression stage driven by a aingle impulse stear turbine stage that is in series with the steam generator. Auxilfary elrculation is provided by electrically driven centrifugal circulators powered by separate and individually driven alternators.

\section{Reactor Core}

The reactor core 1s composed of 211 hexagonal fuel and radial blanket elements containing the fuel and blanket rods. The elements, which are 
$10 \mathrm{ft}$. In total length and about $61 / 2 \mathrm{in}$. across the flats, are supported from a top-mounted single grid plate to which each element is rigidly attached; they are clamped to the grid plate solely at their "cold" ends. The grid plate, which consists of an $11 \mathrm{ft}$. diameter, $2 \mathrm{ft}$. thick disc with closely spaced 6-in. diameter holes to accomodate the circular extensions of the fuel elements, is itself top supported by a surrounding cylinder connected to the liner of the top penetration in the PCRV. The clamping of the fuel elements to the grid plate, as well as the means for operating a variable orifice within each fuel element, is facilitated by providing individual small penetrations above each element in the top access plug.

In the reactor core there are 27 control fuel elements, each of which contains a movable control rod. Twenty-one of these rods are operated as conventional control rods for normal control, burnup, and shutdown requirements; each has a reactivity worth of approximately $\$ 0.85$. Some of these rods will normally be fully or partially inserted in the reactor core during power generation. The other 6 control rods provide additional shutdown capability and are a backup emergency shutdown system. These 6 rods have a reactivity worth of $\$ 1.60$ each. They will always be fully withdrawn from the core during power generation; therefore, they are not subject to burnup or to irradiation heating as are the conventional control rods.

All control rods are physically identical except that surface roughening is used to enhance the heat transfer from the 21 standard control rods. 
The 6 secondary shutdown rods have smooth surfaces. The neutron absorber material is $\mathrm{B}_{4} \mathrm{C}$. The worth of the rods is established by adfustments in $B^{10}$ Isotope enrichment. The mechanical design of all the absorbers is the same.

The absorber section of the control rod is vented to the surrounding coolant to provide pressure equalization. A vent hole and a metallic filter at the upper end of the absorber section allow the gas to escape to the fuel element inlet coolant stream but prevent particulate matter from leaving the absorber section.

The coolant flow in each fuel element is orificed so that the same hot spot cladding temperature is reached in each element, and on-1ine adjustment of all oriftces 18 provided.

Pressure in the fuel rods and blanket rods is equalized to that of the reactor coolant by collective venting, and the fission gases pass through the vent manifold to the hellum purification systen. (See F1gure 3). This system provides means for detecting and locating a fuel element with falled cladding. This is done by using radioactivity monitors on the vent 11 nes. 


\section{SCHEMATIC OF FUEL ELEMENT PRESSURE EQUALIZATION SYSTEM}

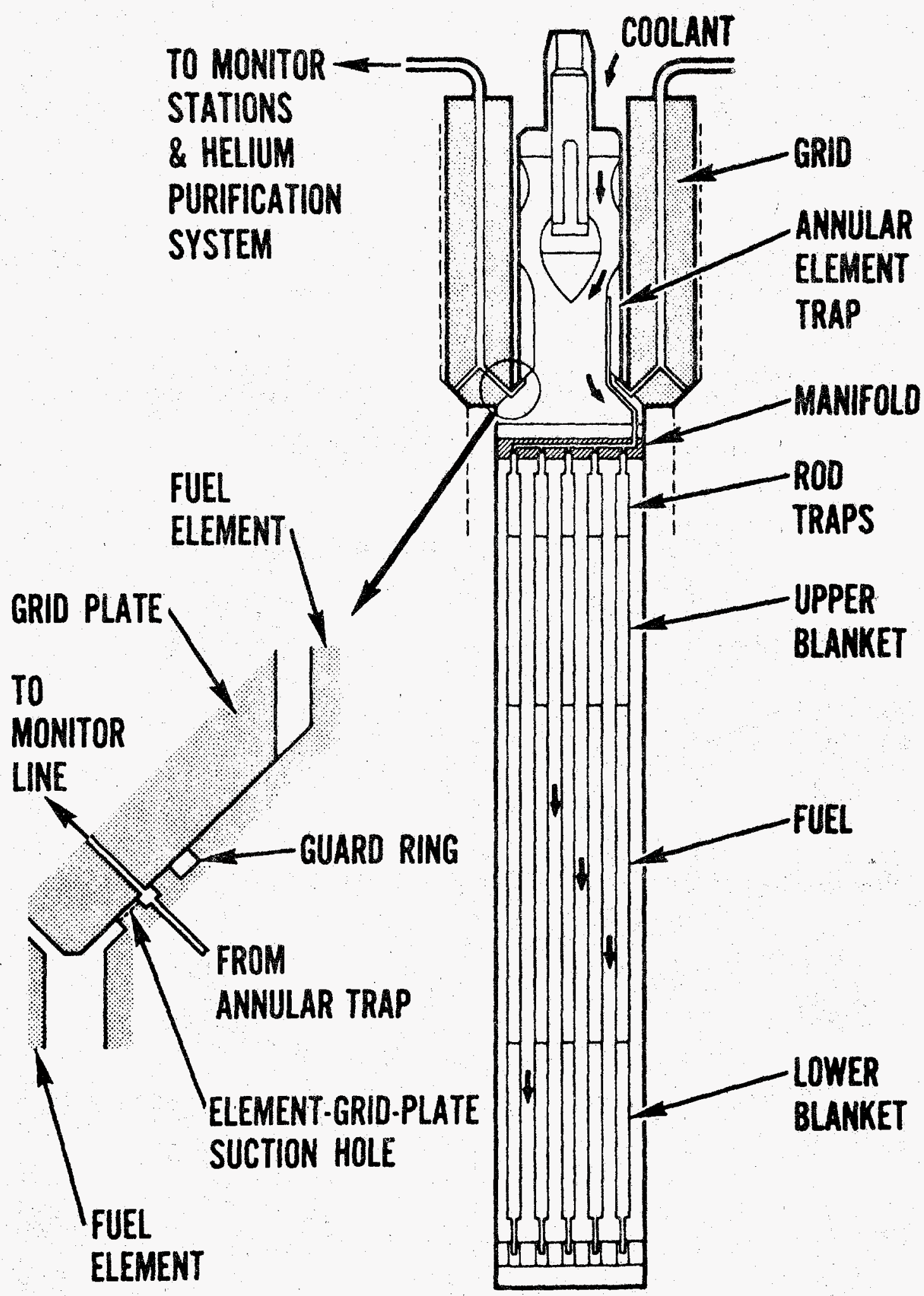


VII

IMPACT OF YORE RECENT GCFR DEVELOPMENT

ON WASH-1089 EVAZUATION

Major Technical Changes Subsequent to WASH-1089

The previous discussion of GCFR development effort since the issuance of WASH-1089 is sumarized as follows:

(a) The modification of certain system parameters notably in fuel cladding temperature.

(b) Further effort on fuel venting (pressure equalization).

(c) A closer allgwent of the GCFR design with the HTGR design to obtain as much benefit as possible from the Fort St. Vrain project and the development program for comerctal HTGR plants.

This work has served to further identify the basic problems associated with the development of the GCFR. These are detailed in the draft development program plan (Draft GA-A10788) and are outlined below.

\section{Component Development Needs}

While the development of the GCFR depends to a significant degree on the successful operation, maintalnability, and reliability of Fort St. Vrain (FSV) and large HTGR's, there are many major problem areas unique to the GCFR design that require extensive developmental effort 
and proof testing, over and above HIGR needs. The fact that such efforts are proposed to be conducted concurrently with increased engineering scaleup efforts on the HTGR introduces special considerations. In addition, the use of a compact arrangement in the PCRV will impose design constraints heretofore extremely difficult and costly to handle in such first-of-akind engineering development programs. Such a complex development effort must be addressed in a detailed and disciplined manner based upon a carefully conceived plan and adequate test factlities.

1. Containment of the entire primary coolant system within the PCRV is fundamental to the GCFR concept. Additional model testing will be needed to validate the design at the higher GCFR pressure (1250 psi vs 700 psi for HTGR), although some of the PCRV development needed for GCFR might be accomplished as part of the HTGR development program, depending on exact timing and nature of needs. Such efforts mist also be integrated closely with all of the major component development and first-of-a-kind engineering efforts.

2. There are a number of unique first-of-a-kind components that represent a significant engineering extrapolation from other firstof-a-kind components, some of which have yet to be designed and built and others of which have yet to be prooftested under actual operating conditions or operated in a reactor plant. These components and their associated maintenance equipment must be developed, fabricated and tested along with related development and proof-test facilities. 
a. The circulator horsepower rating for a 300 MWe GCFR is 4 times that for FSV, and $11 / 2$ times that of the 1100 MWe HTGR's. In addition, the steam drive is based on 2900 psi steam versus 840 psi for FSV.

b. The steam generators for the GCFR are 10 tImes larger than the FSV units in heat transfer surface area, and about the same as proposed for the large HTGR units. Boiling stability for the GCFR at normal load range and at flows as low as $2 \%$ of normal for the shutdown cooling phase has to be provided.

3. Reactor mechanisms such as control drives, orifice drives, and core clamping devices are unique to the GCFR and have to be operated in hot helium with the attendant problems of lubrication, prevention of self-welding, vibration, metallurgical creep and radiation damage in a fast neutron flux environment, although some of the experfence with similar HTGR components may be applicable.

4. A difficult requirement exists to provide spent fuel cooling during removal from the core and transport to a water storage pool. Such requirements will be influenced by the proposed vented fuel concept. 
5. The successful development and proof test of the GCFR refueling system and components also require first-of-a-kind engineering plus testing in the operating environment to demonstrate the adequacy of the design.

6. Special reactor Instrumentation--some continuously operable, other for Inttial test purposes-is required to monttor the gas exit temperature from each fuel element, to measure vibrations and other parameters in the first-of-a-kind plant, and to assure design performance of all components under normal and abnormal operating conditions. Performance and rellability of such Instrumention in a high fast flux and high temperature environment pose very difficult development problems.

7. The GCFR core, because of the use of gas cooling with its heat transfer limitations, has a large core vold fraction which leads to neutron streaming and leakage probleas and may introduce problems relating to the internal shielding of components.

\section{Fuel and Core Development Needs}

In order to maximize the benefits to be gained from other ongoing activitles, the GCFR effort in this category should utilize to the extent possible the spin-off technology from the large scale efforts 
being carried out under the top priority LMFBR program. However, there are for areas unique to the GCFR concept that will require extensive and costly development.

1. While fast reactor physics methods and fundamental data developed by the expertise and from facllities at ANL for the LMFBR program w111 benefit the GCFR program, considerable additional effort will be required to meet GCFR needs. Further work is required on reactivity effects due to the presence of steam introduced into the core as a consequence of a steam generator tube fallure.

2. The fuel rods proposed for the GCFR are different from those planned for LMPBR designs in having a larger diameter, roughened outer surface, and venting of the fuel rods and assembly. Surface roughening may affect the strength of the cladding and irradiation testing will be required to evaluate such effects.

3. Puel venting Incroduces a number of questions that would require substantial development effort, including the rate of release of fission products from the fuel pellets, their diffusion rate through the length of the rod to the charcoal traps, the effects of breathing at the juncture of the fuel assembly vent and the grid plate that occurs with changes in plant load, fission product plateout throughout the vent system, charcoal behavior 
under fast flux irradiation, the maintenance of alignment of seals under bowing and vibration stresses, and lastly the operation of the venting system as a whole under pressure transients with and without cladding leaks. The vented-fuel concept, which is attractive in principle for the LMFBR as well, has not been adopted in any current reactor system. It presents major design difflculties during plant operation and shutdown and during fuel handing, and it weakens the defense-In-depth safety concept by removing one barrier to the release of noble gas fission products. Little test Information on this concept is avallable as yet and much more remains to be done before proof-of-feastbility can be established, including a variety of integral in-pile proof tests of prototypical fuel subassemblies and assemblies and safety tests relating to the vented concept, under a range of operating, transient and shutdown conditions. Fuel handling tests would also be needed.

4. There are heat transfer questions to be resolved as to the effects of rod spacers, fuel-element box walls, and possible rod bowing. Knowledge of the heat transfer over the whole range of flow from full power conditions on down is required for transient and safety analysis purposes. 
5. Plow induced vibration of the fuel rods and of the whole fuel element is a potential problem to be overcone including the possibility of excessive selsmically induced loads.

6. There are questions respecting the behavior of the interfaces at the spacer/fuel rod and the fuel element/grid in the hot helium environment.

7. Difficult problems, common to any fast reactor, are those related to obtaining the desired fuel burnup of $100,000 \mathrm{Hwd} / \mathrm{T}$ and coping with irradiation-Induced swelling and creep for all metal parts in the core. Much reliable data are needed in these areas.

\section{Safety Needs}

In addition to many of the problems that have been raised on other reactors, there are a number of critical safety questions which have been identified for GCFR's beyond those noted above.

1. More detalled assurance Including test data is needed to assure that adequate reliability of core cooling in potential emergency and faulted conditions can be provided. The plant design would need to have several main loops and auxillary loops. If all main loops fall, shutdown cooling of the core would have to be maintained by the auxlliary loops, each of which would require its own electricmotor-driven clrculator and water-cooled heat exchanger. Startup requirements and adequacy of rellability of the auxillary cooling loops must be further analyzed and demonstrated. 
2. Depressurization of the primary coolant system has been considered as the design basis for engineered safeguards in the GCFR. The maximum allowable depressurization rate would have to depend on some type of flow limiting devices in the large penetrations. This subfect is belng reviewed by the Regulatory staff to assess whether the system design can accomnodate the proposed depressurization accident. Assurance must be given that the design provides adequate margin for a more rapid depressurization and for other concurrent fallures.

3. Although analysis Indicates that the reactivity change of the core is small and negative for all conceivable steam concentrations resulting from steam generator tube failures, additional analyses and critical assembly experiments must be carried out to confirm this.

4. The use of a core support system in which the fuel elements are tightly clamped at one end Into a thick grid plate with no additional radial restraint, along with the potential deleterfous effects of such materlals phenomens as radiation damage and stalnless steel creep, has led to detafled questioning by Regulatory and ACRS on the integrity of the system and the reactivity effects under transients and earthquakes. These problems w111 have to be resolved.

5. The adequacy of the proposed protection provided by control system actions backed up by two Independent shutdown rod systems against anticipated transients must be proven. The consequences of fallure of protective action in anticipated translents must be analyzed to establish their acceptab111ty. 


\section{Development Approach}

The current GCFR draft development plan proposed by GGA does not call for many of those aspects of the reactor development program identified in Figure 4. For example, past experience in other reactor programs has demonstrated the vital need for a relatively small reactor experiment in addition to other test faclities to provide an essential contribution to the evidence of technical feasibility, to facilitate teaningful evaluations prior to a combitment for a large scale development program and a demonstration plant program. Considerable weight must be given to the many problem areas which historically have been discovered and solved as an outgrowth of specific operating experience on such experimental reactors. Cases in point are the many problems on small plants such as STR, EBWR, HRE, SIR, SRE, Saxton, EBR-I, EBR-II, Hallam, Fermi, MSRE, EBOR, UHTREX, EGCR, Piqua and BONUS, as well as the British experience with Dounreay.

WASH-1089 pointed out the need for a GCFR reactor experiment (1) to provide more information concerning the physics and safety of GCFR's, (2) to assist in the development and teeting of GCFR components and (3) to provide a facillty for fuel element development testing. Hxperience since publication of WASH-1089 appears to confirm the fact that a sound engineering approach requires a GCFR reactor experiment along with other related efforts outlined in Figure 4 to help establish the technical feasibility and requisite technical basis for this concept prior to full scale comitment to a demonstration plant program. Moreover, such accomplishments appear to be essential to permit meaningful evaluation or acceptance by the utility industry and others. (See Figure 5) 


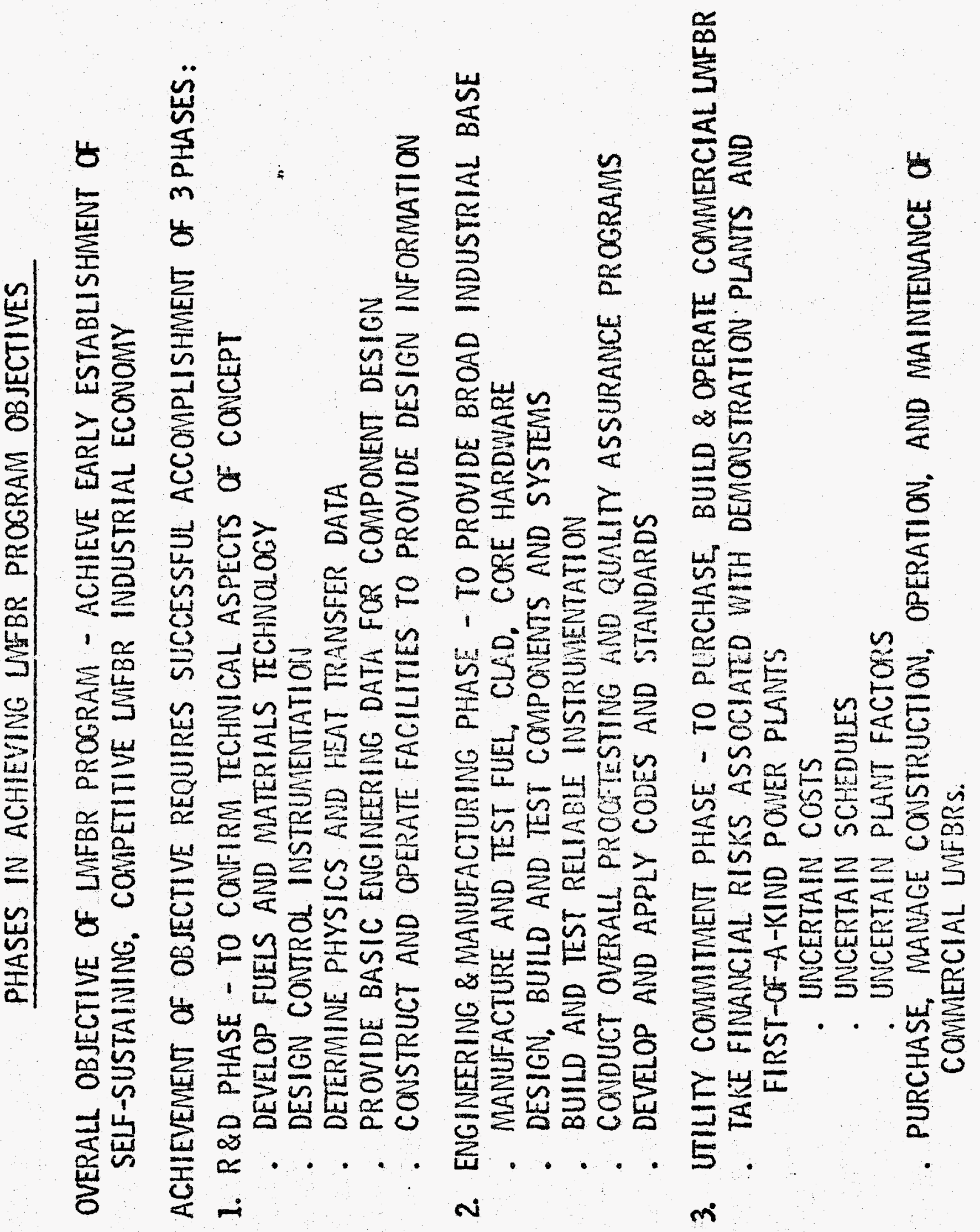




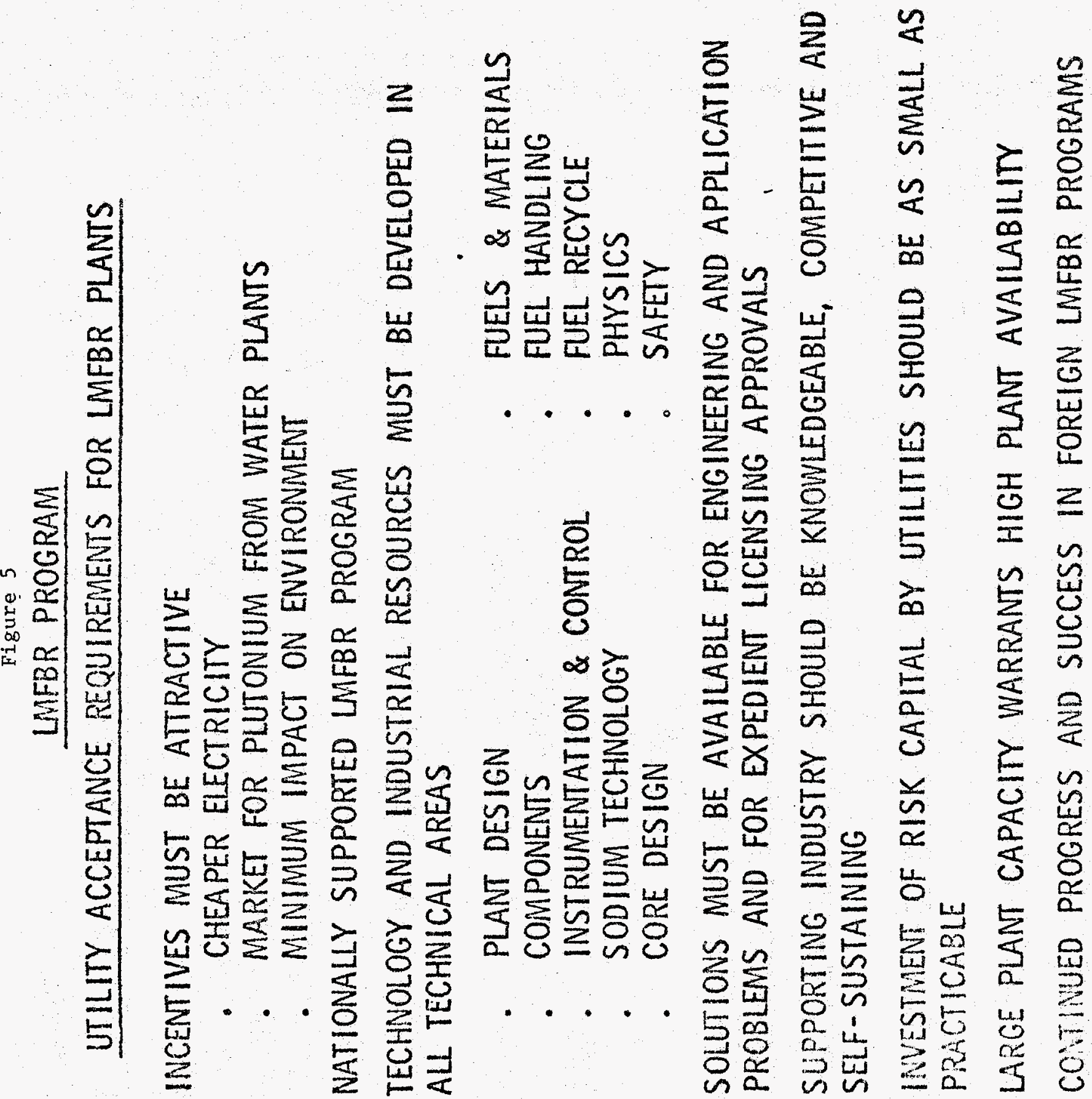




\section{VIII}

\section{CONCLUSIONS}

Progress has been made in further defining the problems of the GCFR concept since the analysis reported in WASH-1089. Wh1le much of the privatelysponsored effort has been almed at a 300 MWe demonstration plant, the overall full-scale plant syatem design has remained largely unchanged and the major developmental and safety losues specific to the GCFR as ourlined herein require resolution. The further defintition of these problem areas, aided by experience to date in the LWR, HTGR and LMFBR programs and discusstons with the Regulatory staff and the ACRS, has served to reinforce the earlier conclusions that a substantial program of development and proof testing would be required to resolve adequately all of the wajor outstanding rechnical issues on this concept.

Based upon the Information currently avallable, it is concluded that on a relative basis there have been no significant changes in the GCFR development status to justify appreciably altering the conclusion of WASH-1089 that considerable research and development effort would be needed to provide the required assurance of safe, rellable and economic operation at the design performance levels. A measured, orderly program similar to that outlined for the WMBR Including fuels and waterlals testing, component test facilities, critical experiments, a reactor experiment affording extensive In-pile fuel testing capabilicy, safety tests, and a demonstration plant program would be required to bring the GCPR forward as an option in the comercial atage. 
The GCFR concept is at an early stage of development with respect to Its englneering base, reactor operating experience, industrial participation and comitment, and funding level. It does not have the benefte of considerable existing fast reactor experfence both in the United States and abroad, such as enfoyed by the LMPBR. Assuming that solutions to the basic and major technological problems could be developed, achtevenent of the potential of the concept as a commercial power plant would require a greatly expanded Government effort with significant industrial particlpation and commitment.

If additional resources beyond those needed for the development and commercial Introduction of the LMPBR were to be made avallable, they could be employed In a worthwile manner to move toward a GCFR experinent and other key test facilities to help establish the technical basis prior to comitting to conduct a parallel breeder development program on the GCFR. The riming and funding for such a program described in earlier reports would need to be reevaluated on a current basis, taking into account status and comitments on the HTGR, LWR and LMFBR programs.

In the absence of any additional resources, the GCFR technology w111 continue to benefit from the substantial efforts on the LIPBR and HTGR technologies, as well as the ongoing development work on the GCFR sponsored by the AEC and private industry. The cumulative direct expenditure on GCFR development by the AEC through FY 1972 has been approximately $\$ 9.0$ million, while private support for the concept from ut1litles over the four year period through 
FY 1972 has been $\$ 5.5$ allion. The option remains open over the next few years for increasing the degree of effort on the GCFR should national energy priorities and the degree of progress on the LWR, LWFBR and HTGR so dictate. 


\section{REFERENCES}

1. Assessment of Energy Technologies - Report on Step 1, AEC-7, November 1971 .

2. Staff Report, A 1000 MWe Gas Cooled Fast Reactor Study for the Alternate Coolant Task Force, USAEC Report GA-7804, General Atomic, July 21, 1967.

3. General Atomic, Addendum to 1000 Mwe Gas Cooled Fast Reactor Study for the Alternate Coolant Task Force, USAEC Report GA-7804 (Add.), Sept. $28,1967$.

4. General Atomic, Addendum 2 to 1000 MWe Gas Cooled Fast Reactor Study for the Alternate Coolant Task Force, USAEC Report GA-7804 (Add, 2), November 12, 1967.

5. General Atomic, Preliminary Development Plan for the Gas Cooled Fast Reactor (GCFR), GA-8257, Oct. 1967.

6. Gulf General Atomic, Design Study of a 330 MWe Gas Cooled Fast Reactor Denonstration Plant, Feb. 1969 (private G.A. data)

7. Gulf General Atomie, Design of a Nuclear Steam Supply System for GCYR, GA-10064, May 15, 1970 (private G.A. data)

8. Gulf General Atomic, Gas Cooled Fast Breeder Reactor, Preliminary Safety Information Document, GA-10298 (2 Vols.), Feb. 15, 1971. 